\title{
Aging and the Necessity of a Radical Reform of the Canadian Pension System
}

\author{
Jacques Henripin ${ }^{1}$ \\ Professor emeritus \\ Université de Montréal \\ jacques.henripin@sympatico.ca
}

\begin{abstract}
Compared to the 29 other members of OECD, Canadian workers must satisfy themselves with a rather timorous public pension system, particularly those who earn a middle or higher income. This weakness is somewhat corrected by private pension organizations, but only a third of employees are covered by them. The author proposes that all workers have access to such programs and even that they are mandatory. There would be many of them; they would function on the basis of capitalization; they would be public or private. The choice of the capitalization financial principle is almost essential, due to future population aging. The author displays his convictions about these proposals, as well as practical ways to implement such a program.

Key Words: Population aging, Canadian public and private pension plans, pay-as-you-go and capitalization financial principles.
\end{abstract}

\section{Résumé}

Par rapport à ceux des 29 autres pays de l'OCDE, les travailleurs canadiens doivent se satisfaire d'un système de pensions publiques plutôt timoré, particulièrement ceux qui gagnent un revenu moyen ou élevé. Cette faiblesse est corrigée, peut-on dire, par des systèmes de pensions privées, mais seulement le tiers des employés en bénéficient. L'auteur propose que tous les travailleurs aient accès à de tels programmes et même qu'ils soient obligatoires. Il y en aurait plusieurs ; ils seraient gérés suivant le principe de capitalisation ; ils seraient publics ou privés. Le choix du principe de capitalisation est presque essentiel, à cause du vieillissement futur de la population. L'auteur expose ses convictions là-dessus, de même que des moyens pratiques de réaliser un tel programme.

Mots-clés : Vieillissement de la population, systèmes canadiens de pensions publiques et privées, principes de financement « pay as you go » et de capitalisation.

1. Thanks to my son Olivier, and to the two readers of this text, its presentation is much better than it would have been without their help. 


\section{Introduction}

Canadians are usually proud of their health insurance system as well as some other elements of their public life with socialist leanings. But most of them ignore the weakness of their public pension system. Canada is among the puniest countries of the western world in terms of access to what might be called a respectable public pension system. By "respectable," I mean a system which secures a reasonable pension for everyone who has been working for 35 to 40 years of his or her life.

What is reasonable? In its annual analysis of its members' public pensions, the Organization for Economic Cooperation and Development (OECD) uses a statistical concept that may serve as a guideline (OECD, 2007:34-37). It is called "net replacement rate of mandatory pension programs," that is, the ratio of the average pension entitlement, net of taxes, to the average preretirement earnings, net of taxes and contributions. For the thirty members of OECD, the average ratio for men is $70 \%$; for Canada, it is $57.4 \%$. Canada ranks $23 \mathrm{rd}$ and only 7 countries have a lower rate, among which is the USA, with 52.4\%. It is worth underlining a Canadian particularity: Canada is relatively "generous" for low-earning pensioners: for those whose preretirement earnings were half the average, the net replacement rate is $89.2 \%$ and Canada ranks 12 th. But the rate is only $30.8 \%$ for earnings which are twice the national average and Canada's rank is 26th in that case. Here are some details for the OECD countries and for Canada:

\begin{tabular}{lcc}
\multicolumn{1}{c}{ Income } & \multicolumn{2}{c}{ Net Replacement Rate } \\
\hline \hline & 30 OECD Countries & Canada \\
\cline { 2 - 3 } 50\% of the national average: & $83.8 \%$ & $89.2 \%$ \\
75\% of the national average: & $74.0 \%$ & $68.3 \%$ \\
100\% of the national average: & $70.1 \%$ & $57.4 \%$ \\
150\% of the national average: & $65.4 \%$ & $40.0 \%$ \\
200\% of the national average: & $60.7 \%$ & $30.8 \%$ \\
\hline
\end{tabular}

The table shows that the net replacement ratio decreases with increases in income, but at a much greater pace in the case of the Canadian public pension system: according to the figures above, the relative decline is about $28 \%$ for the 30 OECD countries and $65 \%$ for Canada. Of course, as we will see, the Canadian public system is completed by other sources of income, particularly by private pensions.

We first look at the sources of income for the elderly in Canada. The two main elements of Canada's public pension will then be described briefly, followed by an analysis of their weaknesses, with particular attention being given to their financial principle (pay as you go). Finally, different 
proposals for reform will be examined with two main purposes: setting up a more efficient financial system (which secures a higher pension for a given contribution) and ensuring a reasonable pension for all "full time workers."

\section{What are the Elderly Sources of Income?}

Long Mo provides a very useful description of the sources of income for Canadians aged 65 and over in 2002 and 1980, based on Statistics Canada's data (Long Mo, 2005). The reader will find its most salient aspects in Table 1. Public pensions are divided here between what Long Mo calls "net transfers" (Old Age Security [OAS] plus Guaranteed Income Supplement [GIS]) and Canada Pension Plan (including the Régime des rentes du Québec). We shall describe these elements later on. In 2002, public pensions were responsible for $31 \%$ of the elderly's total income. In 1980, that figure was about the same $(30 \%)$. Private pensions were a little more important than public ones in 2002 (32\%), but not in 1980 (12\%). In fact, they are the most important source of income since 1993.

One of the most remarkable features of Table 1 is the enormous difference in sources of income between rich and poor. In 2002, the mean income was $\$ 14,400$ for the lower quintile and $\$ 54,100$ for the upper one. The poorest relied on public pensions for $89 \%$ of their income (65\% on Old Age Security and $24 \%$ on Canada Pension Plan). At the other end of the income distribution, the public pensions contribution was, on the whole, negative and the main source of income was work (43\%), followed by private pensions $(40 \%)$.

It is interesting to amalgamate pensions related to and determined by contributions during working life, which excludes transfer payments (OAS and GIS). In 2002, pensions based on contributions represented 52\% of total

Table 1. Percentage Composition of Income by Source for each Quintile of Canadians aged 65 and over, 2002

\begin{tabular}{lcccccc}
\hline Source of Income & Total & $\begin{array}{c}\text { 1st } \\
\text { quintile } \\
\text { (lower) }\end{array}$ & $\begin{array}{c}\text { 2nd } \\
\text { quintile }\end{array}$ & $\begin{array}{c}\text { 3rd } \\
\text { quintile }\end{array}$ & $\begin{array}{c}\text { 4th } \\
\text { quintile }\end{array}$ & $\begin{array}{c}5 \text { th } \\
\text { quintile } \\
\text { (upper) }\end{array}$ \\
\hline Net transfers* & $12 \%$ & $65 \%$ & 40 & 20 & 6 & -13 \\
Canada Pension Plan ** & 20 & 24 & 31 & 25 & 20 & 12 \\
Private pensions & 32 & 4 & 17 & 32 & 40 & 40 \\
Investments & 13 & 5 & 8 & 10 & 11 & 18 \\
Work & 24 & 2 & 5 & 12 & 23 & 43 \\
\hline${ }^{*}$ Old Age Security and Guaranteed Income Supplement & & & & \\
${ }^{* *}$ Including the Régimes des rentes du Québec \\
Source: Long Mo, 2005, p. 146.
\end{tabular}


income. That proportion varied among quintiles: $28 \%$ for the lower quintile; $48 \%$ for the second; $57-60 \%$ for the three upper quintiles.

That is a fine diversity of income sources, but some elements are questionable: labour income normally has a short duration and investments constitute a minor element, except for the well-off; there is no provision for sharing years of life expectancy among individuals, something that pension systems do; and transfer payments, almost by definition, have a limited number of beneficiaries. It is therefore probably wiser, for ordinary citizens, to rely mostly on public or private pension funds. There is no problem in combining both, as is the case in Canada. But the combination is not quite satisfactory: the Canadian public system is rather modest and the more generous private pension funds are limited to a minority of workers. We will come back soon to a critical examination of the Canada Pension Plan. For the moment, though, let us describe briefly the major aspects of the Canadian public pension system.

\section{The Two Elements of the Canadian Public Pension System}

The original component of this system, Old Age Security, has been supplemented more recently by another element, the Guaranteed Income Supplement (GIS). Their combination ensures an annual minimum income of $\$ 13,400$ for a single person. The only requirement is residence in Canada (more precisely, 40 years of residence after the age of 18 for a full pension). For the last few years, its basic element, OAS $(\$ 5,900)$, is reduced progressively when the annual income reaches $\$ 60,000$ and disappears at about $\$ 110,000$. It is price-indexed and might be considered a form of social assistance. The total amount spent by the federal government for OAS and GIS was $\$ 30.3$ billion in 2006-2007 (about 2\% of GDP).

The second component of the system, the Canada Pension Plan (CPP), is linked to past contributions of retirees. It was established in 1966 and is administered by the federal government, except for the province of Québec, which manages its Régime des rentes du Québec separately. The two systems are almost perfect twins and in the rest of this paper, my references to the Canada Pension Plan should be understood as referring to both. This regime is characterized by the following features: 
- It offers a pension equal to $25 \%$ of the average preretirement income (exclusive of those $15 \%$ of working years where one's income was lowest), assuming 40 years of contribution. Earlier salaries are adjusted to variations in the average national salary.

- All workers are submitted to the system, except for those who earn less than $\$ 3,500$ a year and the system has a ceiling: it ignores all revenues over the average national salary (now $\$ 41,000$ ).

- Due to that ceiling, the amount of the maximum annual pension is now $\$ 10,250$.

- The system is primarily financed according to the pay-as-you-go principle (PAYG), which means, essentially, that pensions distributed during a particular year are financed by the contributions made in the same year. However, revenues are, for the moment at least, slightly higher than expenses: in 2006, revenues were $\$ 43.4$ billion and expenses $\$ 34.4$ billion (2.3\% of GDP). As a result, a fund is accumulated. In 2007, the CPP (not including the Québec twin) had about $\$ 117$ billion to invest. A rough estimate including Québec would bring the amount to about $\$ 140$ billion. That makes the CPP's financial basis a hybrid system: it is mostly PAYG, with a fragment of financial capitalization.

- In the first few years after its establishment, there were few pensioners per contributing worker and the contribution rate was modest: $3.6 \%$ of the salary covered by the system, shared equally between the employee and the employer. With the aging of the population, and expected future aging, this rate had to be adjusted to $9.9 \%$, also equally shared.

\section{Advantages and Weaknesses of the Canadian Public Pensions System}

One thing is clear: the Canadian public pension system is strongly oriented towards ensuring a minimum living standard for every one, including those who never worked. It is also rather timid, if not timorous, in contributing to a decent pension for all workers. In other words, Canada leaves a remarkably large proportion of retirement replacement income to private initiative: it ensures at best only $25 \%$ of the average past yearly income (under an income ceiling of $\$ 41,000$ ). Employers (including governments for the benefit of public servants) have succeeded in assuming an appreciable part of the noncovered income; the rest lies fallow: the majority of Canadian 
workers have no access to a supplementary pension system. It is interesting to note, in passing, that even the United States is more successful than Canada in covering its workers with a public pension system. This is a first main weakness.

A second weakness is the way the CPP is financed: the pay-as-you-go principle. Pensions distributed during a given year are financed by contributions collected during the same year. Most Western countries, if not all, have adopted that principle. Opposed to that is a system referred to as "capitalization," through which subscribers pay a regular contribution during their whole working life. These amounts are used by the fund administrators to buy shares and bonds, so that the fund is fed by two sources: participants' contributions and the investment returns collected by the fund administrators. That supplementary source of revenue makes quite a difference, as we shall see in the next section.

When the population is relatively young, a PAYG system can function with relatively low contributions, since there are many workers who contribute per pensioner. However, with the aging of the population, there are fewer and fewer workers for each pensioner. In countries like Italy, France, and Germany, all of which are characterized by generous pensions based on the PAYG principle, the situation will soon become unsustainable; in the United States, it will become very difficult, as indicated by various recent proposals to lighten the costs of the system. In Canada, population aging will have the same effect as in other countries, but the object submitted to this effect is much smaller. One might say that the Canada Pension Plan is "saved" by its stinginess, so that there is ample space for a more efficient capitalization system. In fact, as we have noted, that space is partially, but by no means entirely, occupied by employers' private plans. In 2003, only $39 \%$ of Canadian employees were covered by these private plans, and that percentage is diminishing (Morissette and Ostrovsky, 2006:45); these programs were responsible for $30-32 \%$ of elderly income, more than the contribution of the almost universal Canada Pension Plan, which, despite its modest contribution to retired workers, absorbs as much as $10 \%$ of their income.

To put it simply, Canada does not offer a respectable pension system to all its workers. What is the solution? To remedy that situation by enlarging the present pay-as-you-go system would be unsustainable within 25 years, as it shall be in Italy, France, and Germany (Bongaarts, 2004; Robson, 1996:22). It seems that Canada should adopt the capitalization model, either to replace the present CPP-RRQ system, or to complete it by a compulsory capitalization system. It is sometimes argued that the RRSP (Registered Retirement Savings Plan) is a substitute for the CPP deficiencies. That is partly true, but 
the RRSP does not play an important role of pension systems: to equalize or share the duration of retirement period between individuals; everyone has to bet on the income necessary to cover his or her retirement duration.

\section{The Advantage of the Capitalization Financial Principle}

It should be obvious that a pension system financed only by contributions is more expensive than one which adds a second source, especially if that second source is "invisible." Let us illustrate the difference by using a very simple model. Assume that a generation is characterized as follows:

- $\quad$ Every worker (woman or man) enters the labour force at the age of 20 and retires at 65 .

- $\quad$ Salary is 60 units per year at age 20; it increases progressively up to 90 at 35 years of age, 100 at age 50, and then decreases slowly to 93 at age 65 . The annual average is 90 units.

- All workers contribute $10 \%$ of their salary to a pension plan.

These contributions are accumulated in a fund that belongs solely to that particular generation, so to speak, and the total amount is intended to pay for the pensions after the age of 65 . According to the specifications of our model, the sum of contributions, at the age of 65 , is 405 units per person; with an average life expectancy of about 19 years after retirement, this allows for a pension of 21 units per year, which amounts to only $23 \%$ of the average salary. This percentage is close to the replacement rate of the Canada Pension Plan.

Let us note also that the latter calculation does not include any interest or dividend on any kind of securities or loans. That, again, is close to the Canadian system, which is fundamentally a pay-as-you-go scheme, although it also contains a small fund which produces some return on loans.

Our model was designed as a "capitalized" system, the main characteristic of which is that each generation constructs its own fund during its working life and uses it only after retirement age. Of course, it would be foolish to leave the fund idle and not use it to gain interest or dividends by buying securities on the stock market or other investments. One is astonished by the huge contribution added by this supplementary source of revenues. Table 2 presents the most significant elements of the calculations necessary to compare the "idle" funding (no return on capital lending) with the total "revenues" (contributions plus returns on loans) of an "active" funding, according to different annual rates of return (2,3, and 4\%). 
Table 2. Total Contributions, Total Returns during Working Life and during Total Life, and Annual Pension, according to Different Annual Rates of Return: 0, 2, 3, 4\%

\begin{tabular}{|c|c|c|c|c|}
\hline $\begin{array}{l}\text { Annual } \\
\text { rate of } \\
\text { return }\end{array}$ & $\begin{array}{l}\text { Cumulated } \\
\text { contributions } \\
\text { at age } 65\end{array}$ & $\begin{array}{l}\text { Cumulated } \\
\text { contributions and } \\
\text { returns at age } 65\end{array}$ & $\begin{array}{l}\text { Amount corrected } \\
\text { for returns after } \\
\text { age } 65\end{array}$ & $\begin{array}{l}\text { Annual } \\
\text { pension }\end{array}$ \\
\hline $0 \%$ & 405 & 405 & & \\
\hline $2 \%$ & 405 & & & \\
\hline $3 \%$ & & & & \\
\hline $4 \%$ & 405 & 1,045 & 1,538 & 81 \\
\hline \multicolumn{5}{|c|}{$\begin{array}{l}\text { lote: Monetary units are totally arbitrary. Annual salary varies from } 60 \text { at age } 20 \text { to } 100 \text { at } 50 \text { and } 93 \text { at } 65 \text { years of } \\
\text { ge. Contribution is } 10 \% \text { of salary. The correction appearing in the penultimate column takes into account the fact } \\
\text { at the fund does not disappear when the generation reaches the age of } 65 \text {; at that age, the value of the fund and } \\
\text { s returns only start diminishing. }\end{array}$} \\
\hline
\end{tabular}

The first line of Table 2 corresponds to a pay-as-you-go system with a population having an age distribution similar to the distribution of years lived at different ages (L column in a life table) or, for that matter, by a generation. Comparing each subsequent line with the first gives a clear image of the advantages of a "capitalized" system: even with the rather low annual rate of return of $2 \%$, the annual pension doubles; it is multiplied threefold with a $3 \%$ rate of return and almost fourfold if the rate is $4 \%$.

We assume here that these rates of return are "real" rates, which means there is no inflation. There is no advantage in complicating the model by introducing such a parameter. We also note that, given the experience of pension funds during the last decades, even a real rate of $4 \%$ is rather modest.

One should also keep in mind that the relative importance of returns in the total revenues of the fund depends on the duration of the contribution period: if, for instance, the retirement age is set at 60 instead of 65 , the value of the fund at the age of retirement is reduced by about $10 \%$ when the rate of return is $2 \%$, and by about $11 \%$ if the rate is $4 \%$. Of course, the pension would also have to be reduced because of the increased duration of the pension period. We will address this question later on.

Some readers might be concerned about certain simplistic features of our model: full-time work from 20-65 years of age, and no unemployment, for instance; those elements do not distort significantly the relative advantage of capitalization.

\section{A Look at the Real Age Distribution}

The financial principle generally chosen by Western countries, for their public pension, is the pay-as-you-go system. There are two main reasons for that choice: 
1. The PAYG system does not require any past contribution to receive a partial or full pension; a full pension may even be given to workers who have contributed only a few years. Of course, regulations may prescribe a minimum number of contribution years, but that is largely arbitrary. Such a system is defined by law, so that rights and obligations are only limited by legislators' common sense.

2. The age structure of these countries' population was, and still is, much younger than the distribution of years lived by a generation at different ages according to the life table. The latter distribution is used for calculating contributions and pensions in a capitalized system. But in a PAYG system, the basis is the existing population age structure. Clearly, the age distribution was an appealing factor in the decision taken at the time these systems were instituted - and even today.

Another somewhat ideological "advantage" could be added: the intergenerational financial relations through which adults pay for their parents' pension. This is viewed as a kind of moral virtue in many countries. One wonders why present and future adults should pay for the pension of parents who experienced a quite comfortable economic situation and did not even succeed in raising enough children to fully replace their generation!

A pension system is a device through which the product of adult work is partly devoted to old age needs. Its fundamental mechanism is strongly determined by what one may call the "adult/elderly ratio." In the case of the pay-as-you-go systems, that ratio takes the form of the number of adult workers compared to the number of retired workers at a particular time, which is strongly related to the number of adults (let us say 18-65 years of age) compared to the number of persons 65 and over. Let us call it the "population adult/elderly ratio." For the capitalization system, the corresponding elements are the number of years lived during adulthood by a generation compared to the number of years lived over 65: the "lived-years adult/elderly ratio."

Figure 1 shows the evolution of these two ratios for Canada: a) the population ratio from 1966-2051; b) the lived-years ratio according to Canadian life tables of 1966-2001. Two salient phenomena are worth noticing:

1. The population ratio dropped dramatically from 7.2 in 1966 to 5.1 in 2001; the curve should continue to decrease at about the same speed until 2011, and then more sharply from 2011 to 2031, when it will reach 2.5, according to Statistics Canada's (medium) projection 2 (George et al., 2001). This amounts to a reduction of $65 \%$ in 65 years.

2. The "lived-years ratio" has varied much more slowly: from 3.7 in the 1966 life table to 2.8 in the 2001 life table. 


\section{Figure 1 \\ Ratio of adults to elderly (18-65/65+): \\ Canadian population and life table lived-years, 1966 to 2051}

\section{Ratio}

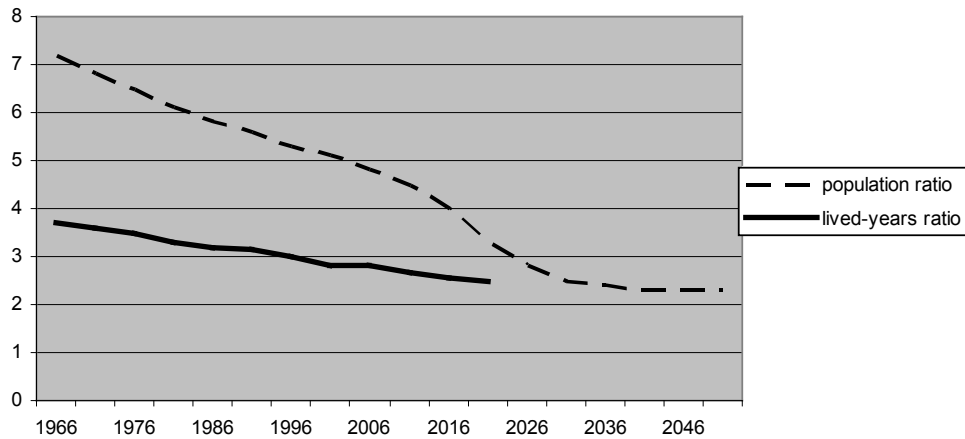

More important, perhaps, previous population ratios have been much higher than the lived-years ratios. In 2001, the former was about 5 adults per elder, whereas in terms of lived years, the ratio was 2.8. The curves imply that the next quarter century will still be characterized by a temporary demographic situation which favours a PAYG system. That advantage is not necessarily sufficient to override the interests and dividends of a capitalized system, but it is still important.

How do the advantages of each system compare? More precisely, how does the return on securities of the capitalized system compare with the advantage of a still relatively young population? Of course, the answer depends on the rate of returns on loaned capital, relative to the advantage of the age composition of the population at a given time. The capitalized system has the obvious and exclusive advantage of returns on securities; a PAYG system, as long as the age composition of the population is younger than the distribution of lived years between adulthood and old age, has the particular advantage of collecting contributions from a large number of working adults for the benefit of a relatively small number of pensioners. The comparison can be figured out quantitatively.

According to the 2001 life table, the ratio of years lived in adulthood on years lived in old age was 2.8; and we have seen that in these conditions, a $2 \%$ rate of return on securities, in the capitalized system, produces a remarkable advantage: a doubling of the pension, given a determined contribution; or, to put it the other way, a given pension can be financed with half the contribution that would be necessary if there were no return on securities. Here, the population age composition plays no role. How- 
ever, it is determinant in the PAYG system. In 2001, the "population ratio" (18-64/65+) was 5.1, compared to a corresponding "lived-years ratio" of 2.8. The advantage of this age composition is obvious: we have here almost twice the number of adults per elder than what the lived-years ratio offers. Yet, to match the benefits of the capitalized system - assuming a $2 \%$ return rate - the "population ratio" should be at least twice the "lived-years ratio," that is 5.6 instead of 5.1. We can then decide that the capitalized system is preferable, at least in terms of financial efficiency, and will be increasingly so with the aging of the Canadian population.

One has to go back to 1960 to find an adult/elder population ratio which is twice the corresponding lived-years ratio. Here is a series of these comparisons:

\begin{tabular}{lccc} 
Year & Population 18-64/65+ & Lived-years 18-64/65+ & Population/Lived-years \\
\hline 1960 & 7.4 & 3.7 & 2.0 \\
1981 & 6.2 & 3.3 & 1.9 \\
2001 & 5.1 & 2.8 & 1.8 \\
2011 & 4.5 & 2.7 & 1.7 \\
2021 & 3.3 & 2.6 * & 1.3 \\
2031 & 2.5 & $2.5^{*}$ & 1.0 \\
\hline${ }^{*}$ Extrapolation & & & \\
\hline
\end{tabular}

Even in 1966, when the Canada Pension Plan was set up, the PAYG principle was less efficient, financially speaking, than a capitalized system associated with a $2 \%$ return on capital, which is rather modest. It is true that until 2010, the superiority of the capitalized system is not very large. It will, though, become more and more important afterwards, as the Canadian population ages.

It is also true that financing efficiency is not the only criterion for choosing a financial device. It is probable that in 1966, governments were eager to favour old workers who, in a purely capitalized system, would have been entitled only to a very meagre pension. It should also be mentioned that the Canada Pension Plan was not purely PAYG: actuaries managed to develop a limited fund, so that provinces could borrow money at a low interest rate (a practice which was later abandoned). Compared to a purely capitalized system, however, the size of this fund is almost negligible (Brown, 1996:59).

\section{Switching to a Capitalized Public Pension System}

This is not a simple and easy move. The main problem lies in the difficulty of financing two systems at the same time. There is obviously no problem 
in setting up a new capitalized pension fund (or many of them, as I shall propose later); that happens every year. But how can the old system finance its liabilities? Suppose the new capitalized system has been set up in 2006. Normally, from then on, all workers would contribute to the new system only and there would be no other source of revenues to finance the pensions promised by the old system.

Let us illustrate that more concretely by going back to our simplified model: we will suppose again that everyone works from 20-65 years of age and dies at the age of 84; that their average annual income is 90 units; and that the contribution rate is $10 \%$, which is practically the same as that of the existing system $(9.9 \%)$. If the return rate of the new system fund is $2 \%$, and the retirement age is 65 , the system would permit an annual pension of 43 units (whereas the old PAYG system can supply only 22.5 units).

All those who were workers or retirees in 2005 have earned a right to a pension from the old system, the size of which depends on their average salary and on the number of subscription years, that is their age. Those aged 60 , for instance, who have subscribed for 40 years, will be soon entitled to an almost full pension (around 20 units). These rights will last until the youngest workers of 2005, who have contributed a few years, have died, that is around 2086. The problem is that in principle, with the switch to the new system in 2006, income earners cease to contribute to the old system and there is no source of revenues to pay for old-system pensions, except for the very small fund of the Canada Pension Plan and the Régime des rentes du Québec. In 2006, the total amount of these funds was about $\$ 140$ billion, whereas the annual amount of pensions to be paid was $\$ 34$ billion. As a result, only four years of the annual expenditures of the old system are covered. Moreover, annual expenditures will tend to increase until 2030, due to the increase in the number of pensioners. From then on, it will start to diminish since the pensioners of the old system will have an increasingly fractional right to a pension. The eldest retirees will have died and been replaced by new retirees whose pension will be partially financed by the new system. That substitution period will last about seventy-five years, after which all pensioners will be totally financed by the new system.

On the whole, the unfunded liabilities of the old system, if it came to a close in 2006 , would be of the order of $\$ 2,000$ billion, which is a third more than the annual gross domestic product of Canada. The annual liabilities of the first 25 years after the old system comes to an end amount to \$34-50 billion and they represent $2-3 \%$ of annual GDP. Thirty-four to fifty billion dollars is not a trifle. It is more than the federal government's annual expenditures for the service of the public debt; it is also twice the combined annual sales of beer, wine, and liquor stores in the country. 
We don't have to consider the technicalities of this transition problem. But it is useful to review briefly what kind of financial strategy could be envisaged.

\section{Some Rough Estimates}

If we suppose that the new system is based, like the old one, on a contribution of $10 \%$ of income (with the same ceiling as the old one), the total amount of the annual contributions would also be about the same as in 2006: about $\$ 40$ billion. Since there is yet no retiree who can claim a pension based on the new system, that amount can be totally devoted to the fund and invested. Following years would produce revenues of the same order, but part of them would have to be devoted to small pensions paid to the "new pensioners." (These first pensions will be small because they are the product of only a few years of contribution to the new system.) It is clear that the fund would soon become quite important, but it cannot be used - at least not totally - to meet the liabilities of the old system, since the advantage of the new one is precisely based on lending money provided by the fund, so that interest and dividends can double or triple future pensions.

One solution to our dual financing problem would be to tax part of the return on the new fund, to finance at least part of the old one. We should remember that according to our simplified model, a return rate of $2 \%$ a year allows for a pension which is double the pension of a PAYG system. That is a formidable advantage. But a $2 \%$ rate is quite modest and it is not impossible that in the long run, an average rate of 3 or $4 \%$ will be observed. Of course, we speak of real return rates, that is, after currency devaluation is taken into account. This would create some financial leeway to manage the transition to the new system. It would probably be possible for the government to tax the return in excess of $2 \%$, for instance, and to use this revenue to pay for old-system pensions. Above a $2 \%$ return, the tax could even be $100 \%$, since that would still leave a palatable advantage to participants to the new system. After all, if such a tax is the price to pay for a new system which can double the pensions offered by the old one, why not?

Due to the small size of the "new" fund during the first decades of its existence, the returns would be small and an appreciable amount of money would have to be borrowed or acquired one way or another by the government (to pay for the "old pensions"); but as the new system approaches maturity, the "tax on returns" (or the collection of any return over $2 \%$ ) would permit reimbursing the amounts borrowed at the beginning of the new system. 
I have made approximate estimates of key values of both systems (old and new) during the transition period, which would last for almost a century. These are very far from what an actuary could do; their only claim is to give a rough idea of the size of the problems involved. Let us assume that:

- the present system has been closed in 2006, but the governments (federal and Québec) have to meet the liabilities of the old system;

- the new system covers the same range of individual revenues as the old one, that is all income over $\$ 3500$ and under $\$ 41,000$ a year;

- the contribution rate of the new system is $10 \%$;

- the real rate of return on the new system's fund is $4 \%$.

In these circumstances, the annual expenditures linked to the old PAYG system would increase from $\$ 35$ billion in 2006 to about $\$ 50$ billion in 2030 and then decrease to zero around 2080. The cumulative value of these amounts is of course enormous: $\$ 1,000$ billion around 2030 and $\$ 2,000$ billion around 2060.

The small funds of the old system (around $\$ 140$ billion) would cover only the first four years. Let us see what a tax on the return of the new system can do. We have supposed that the real return rate is $4 \%$ and that the governments would levy half of it. That would leave a "net rate of return" of $2 \%$ a year for the new pensions, which, despite the tax, would still produce a pension of about half the average salary. Since the new fund would be small during the first decades, the result of this tax would also be relatively small until 2030. At that time, cumulated yearly taxes on the new fund's returns would reach about $\$ 300$ billion, whereas cumulated liabilities from the old system would attain $\$ 1,000$ billion; it is only around 2075 that the former would catch up with the latter. Between 2006 and 2075, an enormous debt would have to be met.

It seems then that taxing part of the returns of the new system would be at best a partial solution. What else could be done? Probably a combination of different means. Here are a few possible strategies:

1. The old PAYG system could be maintained and combined with a new, minimum capitalization one; for instance, a "new" contribution of 5\% would permit a supplementary pension of $20-25 \%$ of average income. Combined with the old system, the total pension would be $45-50 \%$ of average income.

2. Of course, the old system can be kept and combined with a new, stronger, capitalized system. This would resemble the situation of Canadian civil servants and employees of many private firms. In these cases, a 
common arrangement is a contribution of around $12-15 \%$ of salary (over the contribution to the CPP), which allows for a pension close to $60-70 \%$ of the average salary. Such a situation illustrates the advantage of a capitalization system: a contribution $50 \%$ superior to that required by the CPP (15\% compared to $10 \%)$ produces a supplementary pension almost twice as large ( $45 \%$ versus $25 \%$ of average salary).

3. The PAYG system could be abandoned; no further contributions would be collected and the pensions owed to those who have contributed would be financed by the Treasury. Such a liability would be equivalent in size (if not higher), for at least 40 years, to the interest on public debts of the federal and Québec governments (around $\$ 40$ billion yearly at the present time). Such a supplementary expenditure could be reduced by "taxing" the revenues of the new system.

4. In the present CPP system, there are many minor advantages which could be abolished or reduced: death allowance, elimination of the $15 \%$ smallest yearly incomes in the calculation of the average income, for instance. Moreover, the system includes benefits for disabled workers (19\% of total CPP expenses) as well as for spouse and young children. Many rules could be changed. According to a study of the federal and provincial governments (Canada, 1996:33-44), one can roughly estimate that the CPP expenditures could be reduced by nearly $20 \%$ by curtailing these advantages.

These estimates must be interpreted as rough approximations. Again, my main purpose is to illustrate the difficulties related to the abolition of our present system, as well as the advantages of an eventual compulsory capitalized system. Eleven countries, including Sweden, have introduced that last element: a compulsory participation in private pension plans (OECD, 2007:81).

\section{Some Corollary Measures}

\section{A network of private and public pension funds}

If a mandatory capitalized system were ever established for all income earners, even with a ceiling similar to the existing one, the total value of the fund would soon become enormous. Let us assume again that the contribution rate would be $10 \%$ of earned income. Within 25 or 30 years, the value of the accumulated fund would be close to the gross national output and perhaps 
twice that value around 2075. This is a formidable amount of money. But that money is not idle: it is invested in securities, bonds, buildings, etc. In fact, it will have to be invested in all sorts of capital, because an amount which is twice the GNP is approximately half of the national capital stock: airports, highways, houses, factories, hospitals, schools, etc. It would be unwise and even dangerous to leave half of the national capital in the hands of a single board of administrators.

The solution, naturally, is to split this very peculiar market into many institutions. Whether they are public or private does not matter much, since they would all function with the same purpose and under the same state regulations. There could be room for innovation, and some competition between the different institutions would be welcomed. In fact, that is not so different from existing private funds. The main difference would be that each income earner would be compelled to subscribe to one of the funds up to a minimum contribution. It would be possible to switch from one fund to the other.

What would be the role of employers and the present private pension systems? I do not see any necessity to eliminate them, provided they respect the new rules. They have had the historical merit of filling an important gap in our society and, after all, the new system would be a duplicate of them. The main differences would be that: a) access to an adequate pension would no longer be limited to public servants and employees of large enterprises; b) participation in a system which offers a suitable pension would no longer be dependent on a particular employer. Present private pension funds could then be transformed into funds open to any income earner. Otherwise, they could transfer to newly established funds the accumulated rights and corresponding funds of their subscribers.

After all, there is no philosophical or ethical principle that constrains an entrepreneur to ensure that his employees have a wise distribution of their salary between adulthood and old age. That is a personal responsibility, provided an acceptable device exists.

\section{Retirement age and flexibility}

In any kind of pension system, a "normal" retirement age is determined, usually 65 years old. Some countries have already decided to increase that age by one or two years, which is justified by the increase in life expectancy and health improvements. Canada will probably imitate these countries. At a roundtable on retirement income system, Robert Brown, a well-known Canadian professor specializing in these matters, insisted on the necessity to increase the normal retirement age up to 69 years old: "I think it is sale- 
able. In fact, I don't even care whether it is saleable or not. I think it is inevitable" (Brown, 1996:71).

Whatever the decision taken on this issue, a certain degree of flexibility should be maintained. It should be possible, as it is now, to retire at any time from 60-70 years of age (or some other age), provided that pensions are adapted properly so that from an actuarial point of view, neither the retiree nor the fund is unduly favoured. That would represent a change from the many "gifts" of existing private plans in favour of early retirement.

\section{The bizarre advantage of being married}

It is very common for private pension systems to allocate a partial but substantial fraction of one's pension to the surviving spouse. Such a spouse pension is also provided by the Canada Pension Plan, including commonlaw marriages, but with some restrictions. The origin of that allocation is no mystery: half a century ago, most widows had no right to a personal pension; they often lost their husband when their children (more numerous than now) were still young; it was then most desirable to give them at least a partial pension. With the arrival of gender equality, that pension was attributed to widowers, even if very few of them were without a personal pension or revenue.

At the present time, in most cases, at least for widowers, this surviving spouse pension is a kind of reward for the simple merit of having married. It is also true that, even now, many mothers sacrifice part of their adulthood to raising their children and are partly deprived of an adequate pension for that reason. I would propose that the surviving spouse pension be based on the number of years affected by child raising. It would be available for men as well as women. May I mention that a similar element is included in the Canada Pension Plan: in the calculation of the average annual income (which is a basis for determining the size of the pension), years of child raising can be ignored.

\section{Increasing gross domestic product}

This is not a particularly original idea. Indeed, in any situation, increases in national production are welcomed. However, it is especially important in reacting to the challenges raised by an aging population. We have showed the huge cost of getting rid of our present public pension system. Increases in production would facilitate the payment of our present system's liabilities. Pensions vary with the price index, but not necessarily with productivity. 
Consequently, whatever the source of income used to pay for past liabilities, any production increase would lighten the burden. Moreover, aging does not affect only pension costs; it plays an equivalent role for health costs.

Coming back to the pension system, it seems clear that postponing the retirement age would have important benefits. First, postponement has a powerful effect within the pension system itself: for a given contribution rate, retiring at 66 instead of 65 years of age increases the annual pension by $7-9 \%$, depending on the average number of working years. Conversely, the same postponement would reduce the annual contribution rate by $7-9 \%$ for a given pension. Postponing retirement also increases personal income and state revenues, which will be useful in facing the costs of aging.

As a supplementary advantage, a totally funded pension system represents an enormous source of savings available for private or public investments. In fact, it is a compulsory saving machine. That should also contribute to production increase.

\section{Old Age Security}

A great number of less fortunate citizens would have to be exempted from participating, as they are today. It goes without saying that the Old Age Security program, completed by the Guaranteed Income Supplement, should be maintained. Their future cost would be reduced by an increasing proportion of workers who would have access to a gained and sufficient pension.

\section{Conclusion}

In examining the present situation of old age replacement income in Canada, my main purpose was to fill important gaps in the Canadian pension system, so that Canada can join the most successful Western countries or at least take a middle position among them. For the moment, Canada is still far from it, given that two-thirds of workers are deprived of any pension system insuring a satisfactory replacement income. I have also tried to demonstrate that a fully capitalized pension system is much preferable to a PAYG system, given the future aging of the population. Nevertheless, it will be very difficult to get rid of the present system, due to the enormous sum of liabilities in favour of workers who have already subscribed to the system. I have estimated the most strategic elements of that problem and suggested some ways to succeed in that difficult transition. My calculations were rough and in no way can compete with the computations of actuaries. But as the great 
philosopher Karl Popper quite wisely remarked, it is not always necessary for science to be accurate. Neither is it for politics.

\section{References}

Bongaarts, John. 2004. "Population aging and the rising cost of public pensions." Population and Development Review 30(1):1-23.

Brown, Robert. 1996. "Canadian Pension Plan: Financing.” Pp. 59-71 in Round-table on Canada's Aging Society, June 5, 1995. Ottawa: Caledon Institute of Social Policy.

Canada, Finance Department. 1996. Document d'information pour les consultations sur le régime de pensions du Canada. http://www.fin.gc.ca/

George, M.V., Shirley Loh, Ravi B.P. Verma, and Y. Edward Shin. 2001. Population Projections for Canada, Provinces and Territories, 2000-2026. Ottawa: Statistics Canada, Catalogue no 91-520-XPB.

Mo, Long. 2005. "Évolution de la composition du revenu des personnes âgées au Canada entre 1980 et 2002." Cahiers québécois de démographie 34(1):117-147.

Morissette, René and Yuro Ostrovsky. 2006. Pension Coverage and Retirement Savings of Canadian Families, 1986 to 2003. Ottawa: Statistics Canada, Catalogue no 286.

Robson, William B.P. 1996. "Putting some gold in the golden years: Fixing the Canada Pension Plan.” In C.D. Howe Institute, Commentary, No 76.

Organization for Economic Cooperation and Development (OECD). 2007. Les pensions dans les pays de l'OCDE. Panorama des politiques publiques. Édition 2007. In English: OECD, Pensions at a Glance. Public Policies across OECD Countries. 
